\title{
THE CAREER MODEL OF 21st CENTURY ADOPTED BY HIGHER EDUCATION GRADUATES
}

\author{
GABRIELA NEGOIȚĀ
}

West University of Timisoara, Faculty of Sociology and Psychology

\section{(C) 2020 Gabriela Negoiță}

This is an open access article distributed under the Creative Commons Attribution-NonCommercial-NoDerivs license (http://creativecommons.org/licenses/by-nc-nd/3.0/)

DOI: 10.1515/eras-2020-0008

\begin{abstract}
The present paper has identified two career models, the Protean Career and the Boundaryless Career, that can be considered to accommodate higher education graduates' personal and professional needs, as well as the flexibility and adaptability requirements of the current labor market. The research used the data from a tracer study applied online to the graduates of the West University of Timisoara, with a response rate of $25 \%$ (which falls within the response rate for similar studies at the European level).

There has been an increased dynamic of the number of jobs compared to the short period since they have been active on the labor market, especially among male graduates. At the level of individual factors that can influence career success, the importance given to both objective and subjective values is observed. The results have shown that for graduates, income, job security, the possibility of promotion, the use of knowledge, but especially leisure time, are equal priorities, with consistent values in time for both stages of the study. Moreover, there has been a significant negative association between the variables of leisure time and job satisfaction $(\mathrm{r}(522)=-.17, \mathrm{p}<.001)$. Given the mode of action, the high dynamics of jobs, which reflect the much-needed flexibility in the dynamic context of the labor market, and the values that have guided job search, often working and studying at the same time, the pattern of employment career that most accurately describes the career profile of graduates seems to be that of the Protean career (the path with a heart), also called the career of the 21 st century.
\end{abstract}

\section{Keywords}

higher education graduates' career, labor market flexibility, Protean Career, Boundaryless Career, the career of 21 st century

\section{Introduction}

Career development has become increasingly important in the lives of individuals in today's society (for women and men equally). As Hall $(2002,12)$ points out, "the importance of career study is given by the key role that work plays in a person's life".

Career has changed over time (Baruch, 2004), transforming from linear, static (e.g. a single employer/organization), to multidirectional, dynamic, flexible (e.g. career without borders), where job security is no longer offered by the employer, its place being taken by the security of employability (Berntson, Sverke \& Marklund, 2006) or flexicurity (Wilthagen \& Tros, 2004). Flexicurity is an integrated strategy to improve both flexibility and security in the labor market, which seeks to reconcile the needs of employers for flexible labor with the need for worker security.

Perceived career success (Arthur, Khapova \& Wilderom 2005) has changed in turn, and it may be subjective (psychological, feelings of pride and personal fulfilment resulting from achieving the most important personal life goals), specific to "the path with a heart" (Protean 
career) (Herb Shepard, 1984, apud Hall, 1996, 2002, 2004), not only objective (e.g. income, position, type of contract), these being in fact two sides of the same coin.

The responsibility for the individual career has oscillated in time from the individual, to the organization and back to the individual, nowadays. However, in order to know and reach their career potential, the individuals need an adequate educational path, which will provide the necessary development framework (skills, abilities, knowledge) and guidance (career counselling).

\section{Literature review}

From the multitude of theories and concepts that reflect the broad and dynamic framework of career today, given that there has not been a unitary theory so far, two concepts have been selected that can be considered the most appropriate for this research: Boundaryless career and Protean career.

The concept of career has had a multitude of meanings, undergoing changes with the transformations that have taken place in society, economy, industry and labor market, as the career theory has been trying to adapt to the dynamic nature of modern industrial society (Super 1980; Arthur, Hall and Lawrence, 1989; Sullivan, 1999; Arthur and Rousseau, 1996; Baruch, 2004; Sullivan and Baruch, 2009).

Although change has always been with us, it seems that the pace of change is accelerating. Businesses, non-profit organizations, both public and private, all experience a combination of rapid developments in several areas - economy, technology and society in general, with broad implications when it comes to managing people at work and, in particular, their career planning and management (Baruch, 2004).

The availability of numerous competitive theoretical models built over time around the concept of career illustrates the complexity of the career development process. The transdisciplinary interpretations given to the career concept and the theories based on them were influenced by the conceptual dimensions from the sphere of psychology (dispositional/adaptive), sociology (role behavior in organizations, mobility) and economics (accumulation of human capital through experience and education). Regarding the evolution of career theory, Arthur, Hall and Lawrence (1989) proposed an integrative trans-disciplinary approach to theory, in response to the dynamic nature of modern industrial society, leading to new theoretical developments, starting from the perspectives of different social sciences regarding the concept of career, such as:

- Psychology - career as a vocation; career as a vehicle of self-realization; career as a component of the structure of individual life;

- Social Psychology - career as an individual, mediated response to external role messages;

- Sociology - career as development of social roles; career as social mobility;

- Economy - career in response to market forces;

- Political science - career as a staging of self-interest;

- History - career as a correlation of historical results.

Hall $(2002,12)$ adopted a working definition of career, understood as an individually perceived succession of attitudes and behaviors associated with work-related experiences and activities during people's working lives.

Baruch and Rosenstein (1992, apud Baruch, 2004, 59) defined career as "a process of development of the employee along a path of experience and jobs in one or more organizations".

Another definition (Sullivan and Baruch, 2009) describes the concept as a series of relevant individual experiences, including those related to work, both inside and outside organizations, which form a unique pattern throughout the life of the individual. 
This definition takes into account both physical movements, such as between levels, jobs, employers, occupations and industries, and the individual's own interpretation, including his or her perception of career events (e.g., view of job loss as a failure or an opportunity for a fresh start), career alternatives (e.g. viewing limited vs. unlimited options) and outcomes (e.g. defining career success), without neglecting contextual factors such as national culture, economy and the political environment, as well as personal ones, such as relationships with others.

Within the dynamic nature of labor markets, career systems have undergone major changes in recent decades, with a transition from what can be called a linear, one-dimensional career system, to what we now call a multidirectional career system (Baruch, 2004). Traditionally, the linear career or organizational career was defined in terms of the employeeemployer/ employing company relationship, carried out in a rigid, stable context, with possibilities for promotion on a hierarchical scale and appropriate rewards, with job security, offered by the employer, in exchange for the employee's loyalty, according to the old psychological employment contract.

The psychological employment contract has also undergone major changes, with the employee currently providing performance in exchange for lifelong learning and marketability (Sullivan, 1999) and, from an organizational point of view, providing a career that involves stable employment has been replaced by the new contract based on development opportunities (Baruch, 2004), lifelong learning and identity change (Hall, 1996). Given the current volatile and unstable organizational environment, individuals can no longer expect employment throughout their professional life in a single organization or a steady rise in the corporate ladder.

In parallel, the responsibility for choosing and developing the career of individuals has also fluctuated accordingly, from individual to company/organization and back to individual, and the central place given to career in the employment process has become of strategic importance for both individuals and organizations. Career planning and management have become increasingly difficult in the midst of an unpredictable world of accelerated economic, technological and social change, affecting both individuals and various types of employers, giving rise to concepts such as "boundaryless organizations" and "boundaryless careers"dynamic, fluid and multidirectional, defined in the literature as being in opposition to the organizational ones (Arthur \& Rousseau, 1996) - designed to take place in a single occupational setting. The elimination of intra-organizational career paths and fixed organizational charts, specific to the linear career, does not mean the absence of opportunities, but rather implies employment opportunities that go beyond the limits of single occupational frameworks, such paths being considered as careers without borders (Defillippi \& Arthur, 1994).

Starting from the competency-based models of companies, Defillippi and Arthur (1994) define career in terms of competences embedded within three modes of knowledge, with an impact on career opportunities: know-how (comprising knowledge, skills and abilities), along with know-why (individual motivation and identity) and know-whom (encompassing professional and social relationships), very well represented by the principles of a career without borders.

Arthur and Rousseau (1996) argue that within the general meaning given to boundaryless careers (as opposed to traditional careers) there are several specific meanings: (a) the stereotypical Silicon Valley career, in which individuals move beyond the boundaries of different employers; (b) careers such as those of academics or carpenters, which obtain validation and marketability from outside the current employer; (c) those of real estate agents, supported by external relations or information; (d) those that transcend traditional organizational responsibilities for hierarchy and career advancement; (e) those in which the 
individual rejects existing career opportunities for personal or family reasons; and (f) those based on the interpretation of the individual, who can perceive a limitless future regardless of structural constraints.

The perception of career success has also changed its meaning over time. If in the linear career, success was defined by organizations in terms of salaries, promotions and social status, in the multidirectional career success acquires new connotations, the individuals define their success, adding new criteria to the old ones, such as inner satisfaction, balance in life, autonomy/freedom and other self-perceptions (Baruch, 2004).

There is evidence that people who exhibit behavior characteristic of a boundaryless career show a considerably higher level of career success (e.g., Eby, Butts \& Lockwood, 2003 in Arthur, Khapova \& Wilderom, 2005).

For a better understanding Arthur, Khapova and Wilderom (2005) have promoted the importance of using the fundamental ideas of contemporary career theory in the research regarding career success, with emphasis on the interdependence between subjective and objective career success, starting from the definition of career and success in a career, in two, both fundamental and similar ways (two inseparable sides of the same coin):

- $\quad$ Subjective career - reflects self-perception of one's career and becoming;

- $\quad$ Subjective career success - refers to the internal understanding and evaluation of one's career. People have different aspirations and value differently factors such as income, job security, employer location, status, progress at work, access to learning, the importance of work vs. family, etc.

- $\quad$ Objective career - reflects the positions, situations and status, observable from a public point of view, which serve as benchmarks for measuring a person's movements through the social environment;

- $\quad$ Objective career success - can be defined as the external perspective that delimits tangible indicators of the professional situation of the individual such as: occupation, family situation, mobility, task attributes, income or job level. It is publicly accessible and includes the social role and official position.

The concept of Protean career has developed along with the conceptual model of the Boundaryless career, both influencing much of the literature related to the career in recent years. Both concepts refer to the career mobility of the individual as an essential feature of the multidirectional career, which emerged as a consequence of the current context of labor market trading. If in the linear career the frequent change of job was seen rather as undesirable, representing personal instability, now it reflects varied experience or personal targeting, and the use of the advantages offered by the multiple opportunities to find a better job and the search for a better job, good matches between job characteristics and interests, respectively personal needs, are all considered beneficial (Hall, 2002).

The Protean career concept proposed by Hall in 1976 described a career orientation in which the person, not the organization, is responsible, where people's inclinations and core values guide career decisions, the career called by Herb Shepard (1984, apud Hall, 1996, 2002, 2004) "the path with a heart". In the Protean sense, the main criteria for success are subjective (psychological success), compared to the traditional, objective ones (e.g. salary).

However, the concept became popular only in 1996, with the publication of The Career Is Dead - Long Live the Career. Using the metaphor of the Greek god Proteus, who was able to change his form at will, Hall described the Protean careerists as being able to repackage their knowledge and skills to suit the changing work environment, to remain marketable.

Protean careerists are flexible, value freedom, believe in lifelong learning and seek intrinsic rewards at the workplace. 
Perceiving declining stability and increasing uncertainty in the workplace, as well as changes in employment relationships, including reduced job security, Protean careerists have taken responsibility for managing their own careers (Hall, 1996a, 1996b apud Sullivan and Baruch, 2009, 1548-1549).

Hall (1996) states that in the 21st century the career will be Protean (Protean Careers of the 21st Century), led by the person, not the organization, and will be reinvented from time to time as the person and the environment change and psychological success will be the main goal of the career, consisting in the feeling of pride and personal fulfilment resulting from achieving the most important personal life goals (e.g. achievements, family happiness, inner peace).

Several features briefly describe the "Protean Career Contract" (New Career Contract) (Hall, 2002):

- $\quad$ The career is managed by the individual, not by the organization;

- Career is a series of experiences, skills, knowledge, transitions and identity changes that take place throughout professional life;

- Development is continuous, self-directed, relational learning, found in professional challenges; mobility;

Development is not necessarily formal vocational training, retraining, upward

- The ingredients for success have changed;

- $\quad$ From know-how to learn-how;

- $\quad$ From job security to employability;

- $\quad$ From organizational career to protean career;

- $\quad$ By itself in a professional context, by itself as a whole.

- The organization provides challenging tasks, relationship development, information and other development resources;

- $\quad$ Psychological success is the goal.

Subsequently, clarifications have been made to the concept by defining two dimensions: (1) driven by values, in the sense that the internal values of the person provide guidance and measure of success in the individual's career; (2) self-directed in personal career management having the ability to be adaptable in terms of performance and learning requirements (Sullivan \& Baruch, 2009).

\section{Data and methods}

The data necessary for this research analysis were extracted from a tracer study applied exhaustively online to higher education graduates, bachelor's degree level, from West University of Timișoara, that graduated in 2018. The study had two stages (6 and 12 months after graduation) and returned a $25 \%$ response rate (856 valid responses).

\section{Results}

Even if the study was focused on the analysis of the professional insertion of graduates, we found that for many respondents the search for a job began before graduation, for some even before becoming a student.

Chart 1 shows when the surveyed graduates state that they have started looking for a job. The percentages represent the total of those who stated that they have been looking for a job. 


\section{Chart 1: The starting point for a job search}

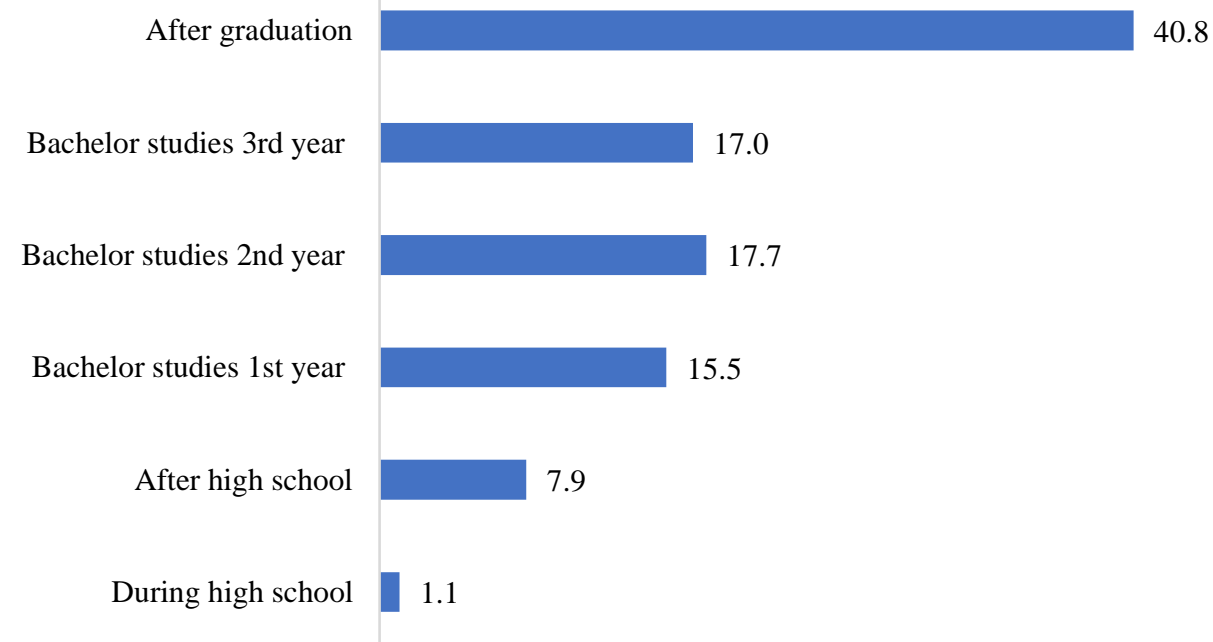

It should also be noted that some of the surveyed graduates found a job before graduating from college. Thus, for the graduates who have declared that they have the status of employee, the moment when they got their job was also evaluated. The results are shown in Chart 2.

\section{Chart 2: Time of employment}

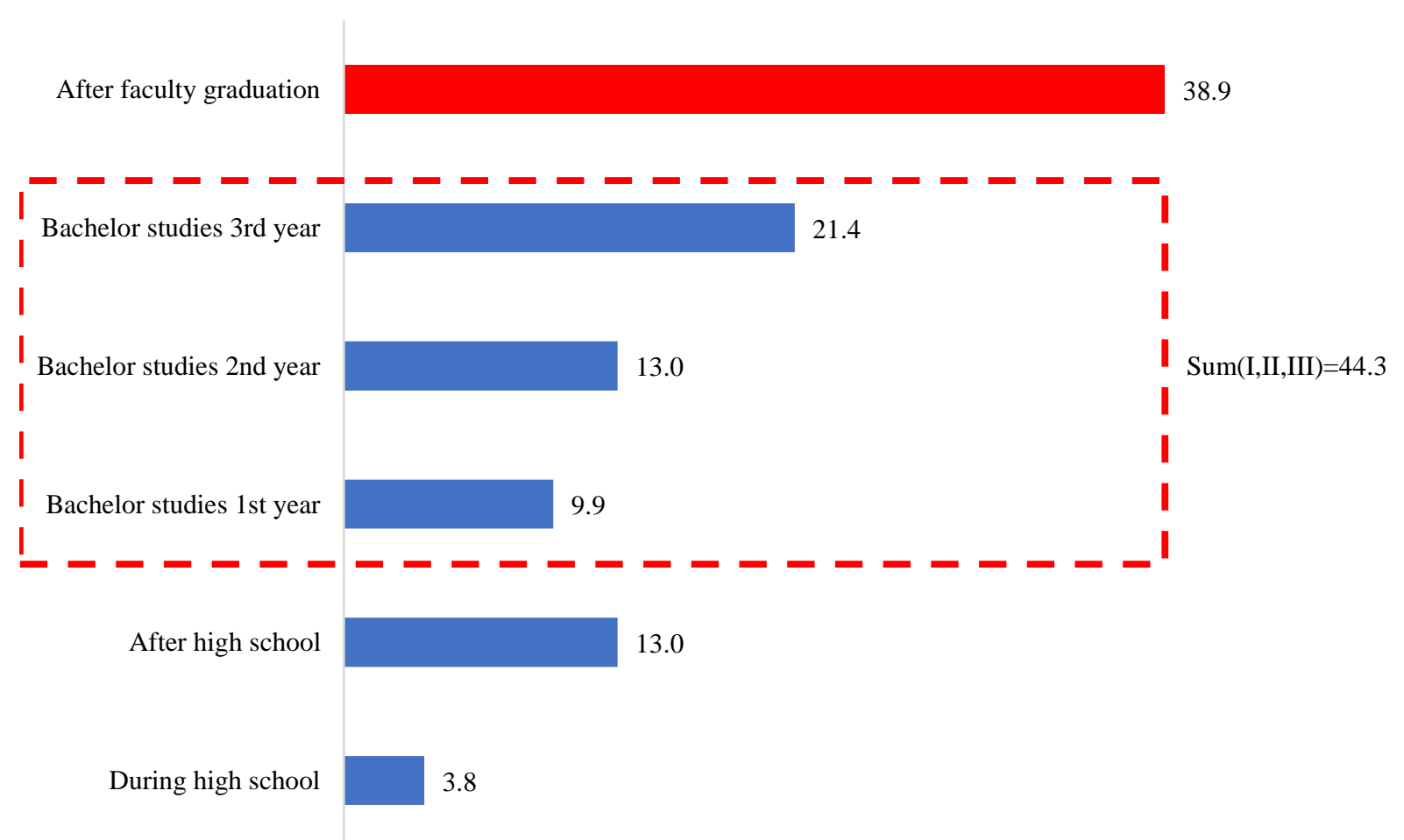

The association between the time of the search and the time of employment is highlighted in Table 1, below. 
Table 1: Employability report

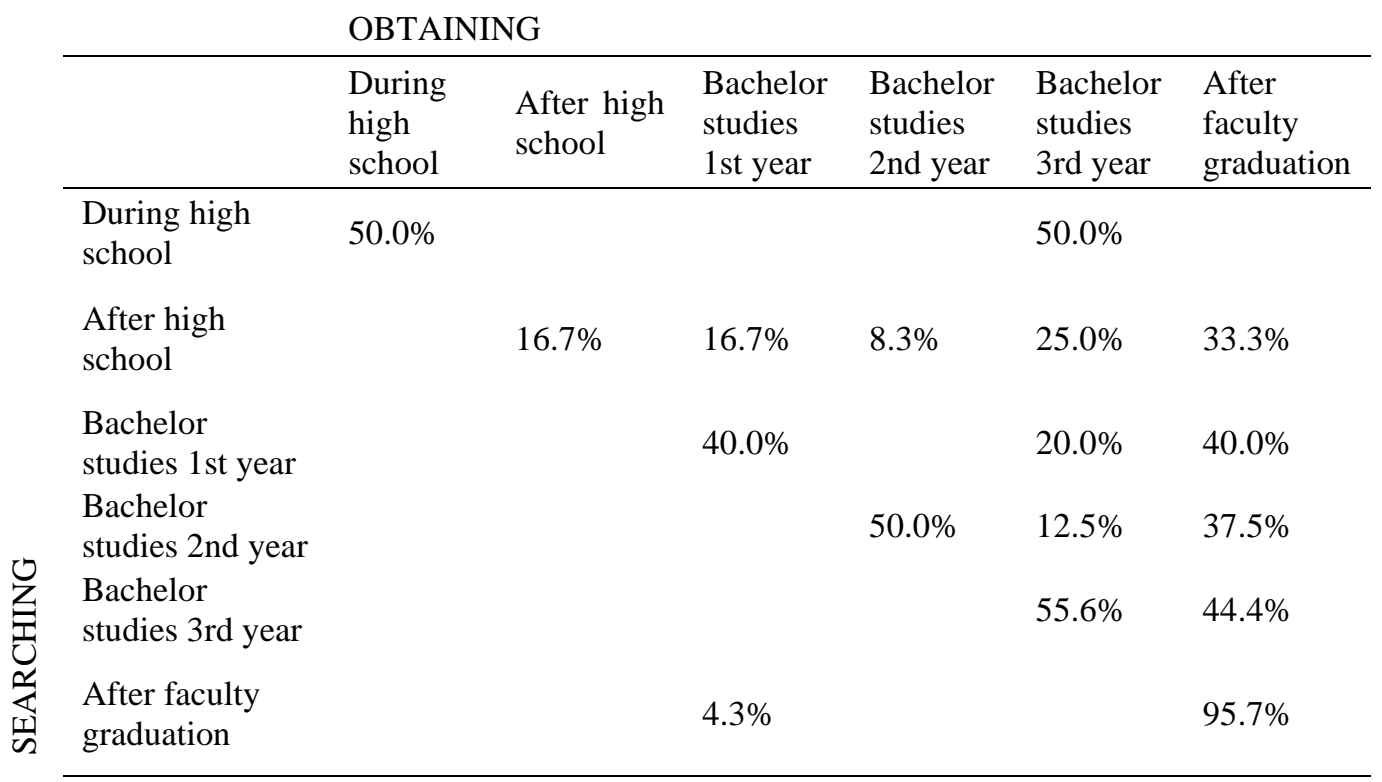

The value of the $\mathrm{Chi}^{2}$ test indicates that this relationship is a significant one (0.000), see Table 2.

Table 2: $\mathrm{Chi}^{2}$ test value

\begin{tabular}{llll}
\hline Pearson Chi-Square & $199.204^{\mathrm{a}}$ & 25 & .000 \\
Likelihood Ratio & 158.399 & 25 & .000 \\
\hline
\end{tabular}

Given that the interval of 6-12 months is still a small one, compared to the economically active lifespan for a person, a relatively high dynamics of the jobs held has been noticed (chart 3).

\section{Chart 3: Number of jobs held}

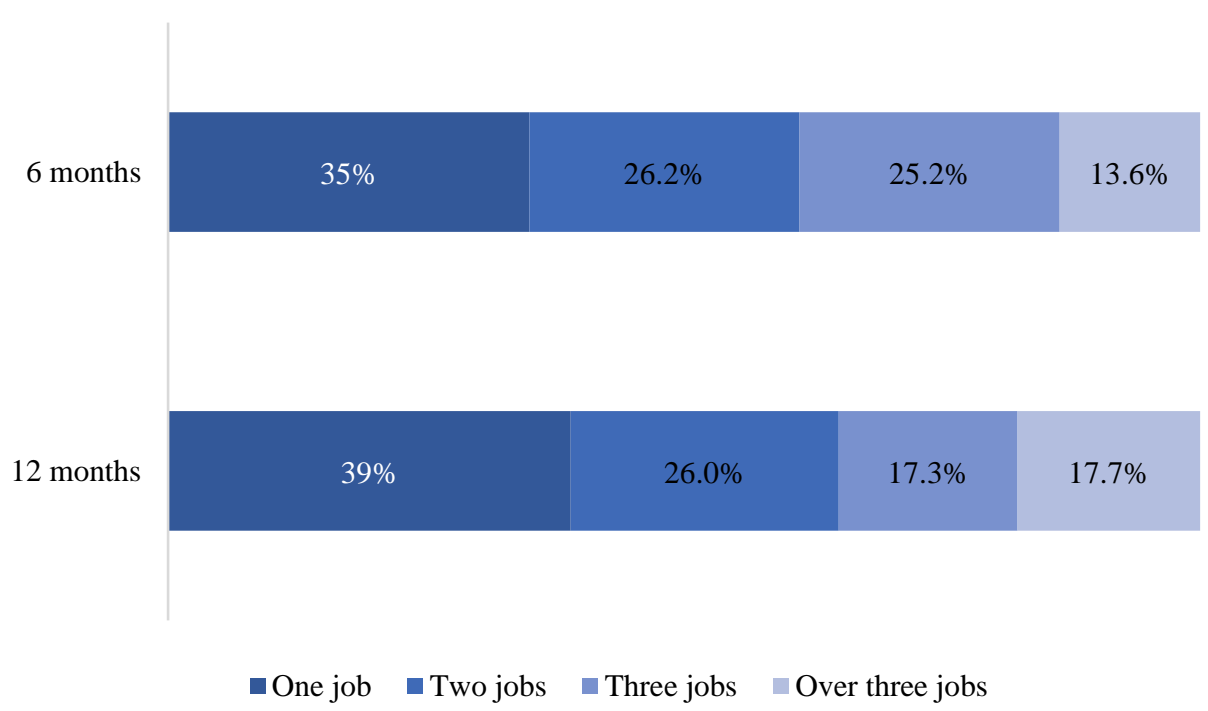

There have not been significant differences between the two groups $\left(\mathrm{Chi}^{2} \mathrm{Sig}=0.149\right)$. Overall, the dynamics is relatively similar. 
Table 3: Number of jobs held by gender

\begin{tabular}{|c|c|c|}
\hline \multicolumn{3}{|c|}{ How many jobs have you had so far? (with employment contract) * Gender Crosstabulation } \\
\hline & Male & Female \\
\hline One job & $32.7 \%$ & $38.4 \%$ \\
\hline Two jobs & $20.4 \%$ & $27.5 \%$ \\
\hline Three jobs & $30.6 \%$ & $18.2 \%$ \\
\hline Over three jobs & $16.3 \%$ & $15.8 \%$ \\
\hline
\end{tabular}

Instead, as shown Table 3, there are differences in labor market dynamics in relation to the gender variable $\left(\mathrm{Chi}^{2} \mathrm{Sig}=0.045\right)$, from our analysis resulting that overall, for male respondents there has been a slight increase in the dynamics on the labor market.

\section{Motivations in choosing a career}

In order to analyze in comparative terms, the values sought or found on the labor market by graduates, 6 and 12 months after graduation, we calculated the Likert 5 weighted mean of graduates' answers, thus $1=$ 'Not at all', $2=$ 'Little', $3=$ 'Moderate', $4=$ ' Much', $5=$ 'Very much'.

\section{Chart 4: Values sought on the labor market}

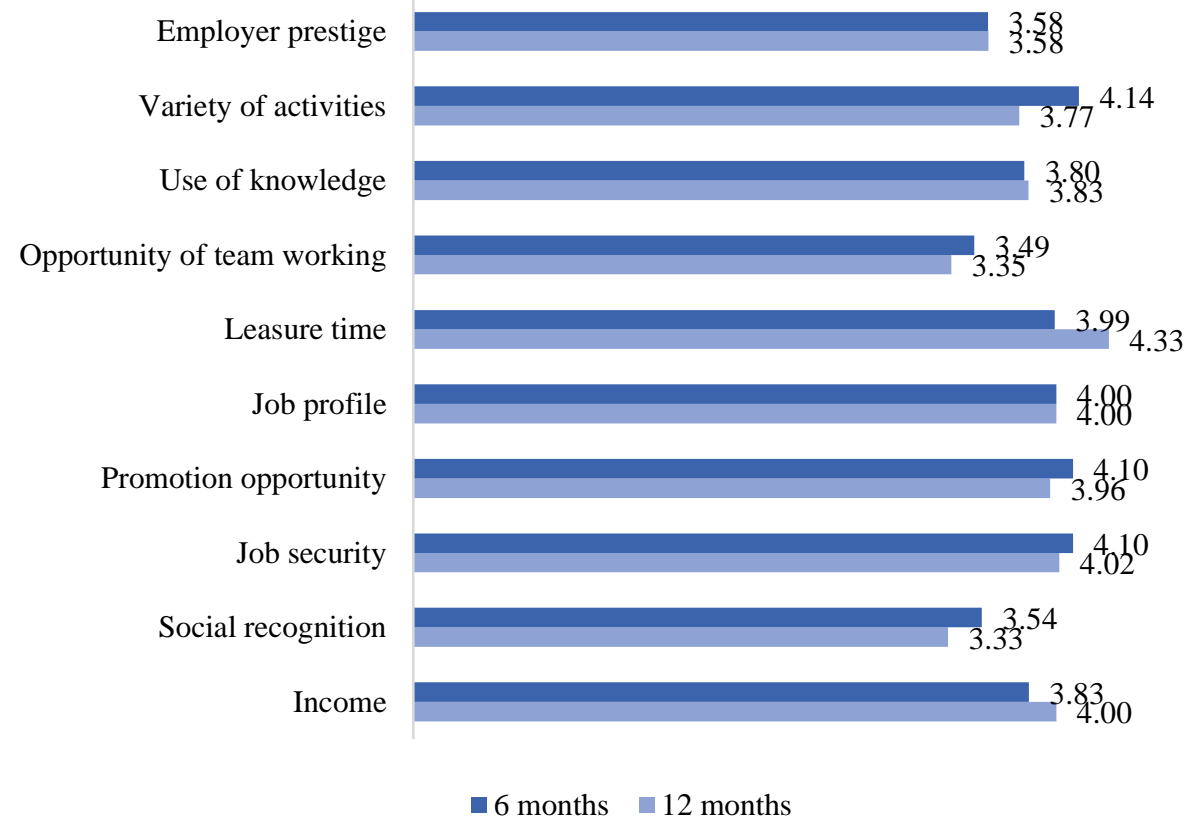

Thus, as shown in Chart 4, both objective values such as job security, income (with a tendency to increase over time, from 3.83 to 4), the opportunity of promotion, the job profile, are very important for graduates, but equally important are the subjective ones, such as the leisure time that increases in importance over time (score 4.33 at 12 months, compared to 3.99 at 6 months) and the variety of activities (with a higher score at 6 months, 4.14 compared to 3.77 at 12 months). 
Chart 5 and 6 show the extent to which graduates found these values in the obtained jobs, both 6 months and 12 months after graduation.

Chart 5: Sought values vs. found values on the labor market (after 6 months)

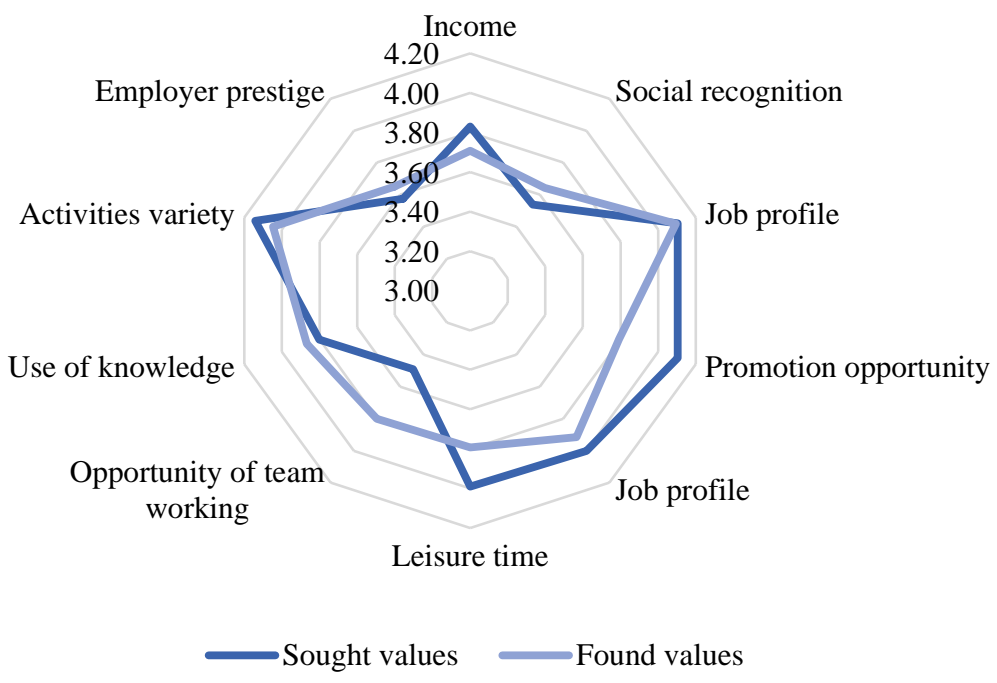

Chart 6: Sought values vs. found values on the labor market (after 12 months)

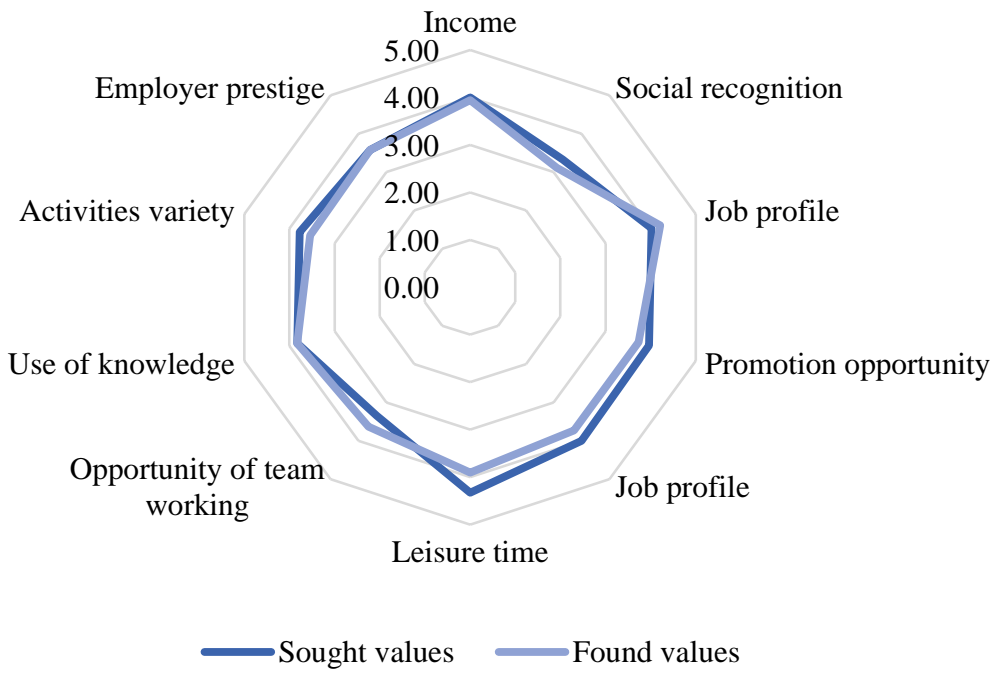

The comparison of the sought values with those found at work shows differences between the two studies, accordingly, a similarity can be found between what motivated the graduates to look for a job and what they actually found at workplace, compared to the situation at 6 months after graduation and 12 months after graduation. What remains below expectations is the leisure time available and the job profile.

Considering motivation an important element in choosing a career, we further performed an analysis of the association between the values sought on the labor market and job satisfaction. 
Table 4: Correlation between the values sought on the labor market and job satisfaction

\begin{tabular}{|c|c|c|c|c|c|c|c|c|c|c|c|}
\hline & 1 & 2 & 3 & 4 & 5 & 6 & 7 & 8 & 9 & 10 & 11 \\
\hline 1. Income & 1 & & & & & & & & & & \\
\hline 2. Social recognition & .25 & 1 & & & & & & & & & \\
\hline 3. Job security & .40 & .49 & 1 & & & & & & & & \\
\hline 4. Promotion opportunity & .48 & .42 & .59 & 1 & & & & & & & \\
\hline 5. Job profile & .18 & .43 & .34 & .33 & 1 & & & & & & \\
\hline 6. Leisure time & .36 & .14 & .30 & .14 & .22 & 1 & & & & & \\
\hline 7. Opportunity of team working & .25 & .37 & .38 & .48 & .41 & .18 & 1 & & & & \\
\hline 8. Use of knowledge & .20 & .39 & .51 & .44 & .49 & .28 & .54 & 1 & & & \\
\hline 9. Variety of activities & .23 & .31 & .45 & .50 & .43 & .11 & .62 & .65 & 1 & & \\
\hline 10. Employer prestige & .33 & .60 & .40 & .46 & .50 & .20 & .42 & .45 & .44 & 1 & \\
\hline 11. Job satisfaction & .07 & .25 & .15 & .19 & .22 & -.17 & .30 & .21 & .28 & .33 & 1 \\
\hline
\end{tabular}

Note: Correlation is significant at $\mathrm{p}<0.001$ ( 2 tailed $)$.

According to Table 4, the results of the Pearson correlation indicated that there is a significant negative association between the variable leisure time and job satisfaction ( $\mathrm{r}(522)$ $=-.17, \mathrm{p}<.001)$. Thus, we can deduce that job satisfaction is all the lower the more the graduates' value the remaining free time left after fulfilling the tasks related to the job. All other values sought at work are positively correlated with job satisfaction, with the exception of income, which, according to the correlation analysis, does not seem to have a very high impact in this regard, in the early career of graduates $(\mathrm{r}(522)=.07, \mathrm{p}=.091)$.

\section{Discussions and conclusions}

At the level of individual factors that can influence career success, the importance of objective and subjective values is equally noticeable. The results show that for graduates, income, job security, the possibility of promotion, the use of knowledge, but especially the free time, with consistent values in time for both stages of the study ( 6 months; 12 months) are equally a priority.

Moreover, considering motivation an important element in choosing a career, we have analyzed the association between the values sought in the labor market and job satisfaction and found that the more lack of free time remaining after performing the tasks related to the job, the lower the job satisfaction is.

All other values sought at work are positively correlated in relation to job satisfaction, except for income, which, according to the correlation analysis, does not seem to have a very high impact in this regard at the beginning of career for university graduates. This is possible if we consider the fact that the perception of career success has changed its meaning over time. If in the linear career, success was defined by organizations in terms of salaries, promotions and social status, in the multidirectional career success acquires new connotations, the individuals define their success, adding new criteria to the old ones, such as inner satisfaction, balance in life, autonomy/freedom and other self-perceptions (Baruch, 2004). It is important to note that career success is a matter that concerns not only individuals but also organizations, as employees' personal success can ultimately contribute to organizational success (Judge, Higgins, Thoresen, \& Barrick, 1999, apud Ng, Eby, Sorensen, \& Feldman, 2005). 
Given the mode of action, the high dynamics of jobs, which reflect the much-needed flexibility in the dynamic context of the labor market, and the values that have guided job search, often working and studying at the same time, the pattern of employment career that most accurately describes the career profile of graduates seems to be that of the Protean career (the path with a heart), also called the career of the 21 st century.

Even if the West University of Timișoara is one of the largest universities in Romania, we cannot extrapolate the results of the study at the national level, therefore further research must include universities from different regions of the country to confirm the results. Furthermore, the labor market in the western part of the country is one with a distinct specificity, with low unemployment, of only $0.79 \%$ in Timiș County at the end of December 2019 (Ministry of Labor and Social Protection, 2019). Also, there are many investments and high demand for labor force at the regional and local level, which is not representative of the labor market in other parts of the country, which once again highlights the need for further studies.

\section{REFERENCES}

Arthur, M. B., Hall, D. T., \& Lawrence, B. S. (Eds.). (1989). Handbook of career theory. Cambridge University Press. Google Books

Arthur, M. B., \& Rousseau, D. M. (Eds.). (1996). The boundaryless career: A new employment principle for a new organizational era. Oxford University Press on Demand. Google Books

Arthur, M. B., Khapova, S. N., \& Wilderom, C. P. (2005). Career success in a boundaryless career world. Journal of Organizational Behavior: The International Journal of Industrial, Occupational and Organizational Psychology and Behavior, 26(2), 177-202.

Baruch, Y. (2004). Transforming careers: from linear to multidirectional career paths: organizational and individual perspectives. Career development international, 9(1), 58-73.

Berntson, E., Sverke, M., y Marklund, S. (2006). Predicting Perceived Employability: Human Capital or Labor Market Opportunities? Economic and Industrial Democracy, 27 (2), 223-244

Defillippi, R., \& Arthur, M. (1994). The Boundaryless Career: A Competency-Based Perspective. Journal of Organizational Behavior, 15(4), 307-324. Retrieved from https://www.jstor.org/

Eby, L. T., Butts, M., \& Lockwood, A. (2003). Predictors of success in the era of the boundaryless career. Journal of Organizational Behavior: The International Journal of Industrial, Occupational and Organizational Psychology and Behavior, 24(6), 689-708.

Hall, D. (1996). Protean Careers of the 21st Century. The Academy of Management Executive (1993-2005), 10(4), 8-16. https://www.jstor.org/

Hall, D. T. (2002). Careers in and out of organizations (Vol. 107). Sage. Google Books

Hall, D. T. (2004). The protean career: A quarter-century journey. Journal of vocational behavior, 65(1), 1-13.

Ministerul Muncii și Protecției Sociale (2019). Statistici șomaj 2019. http://www.mmuncii.ro/

Ng, T. W., Eby, L. T., Sorensen, K. L., \& Feldman, D. C. (2005). Predictors of objective and subjective career success: A meta-analysis. Personnel psychology, 58(2), 367-408.

Sullivan, S. E. (1999). The changing nature of careers: A review and research agenda. Journal of management, 25(3), 457-484.

Sullivan, S. E., \& Baruch, Y. (2009). Advances in career theory and research: A critical review and agenda for future exploration. Journal of management, 35(6), 1542-1571.

Super, D. E. (1980). A lifespan, life-space approach to career development. Journal of vocational behavior, 16(3), 282-298.

Wilthagen, T., \& Tros, F. (2004). The concept of 'flexicurity': a new approach to regulating employment and labor markets. Transfer: European Review of labor and research, 10(2), 166-186. 